\title{
Hubungan Karakteristik Gambaran Radiografi Toraks Distribusi Lesi Paru dengan Prognosis Pasien COVID-19
}

\author{
Fransisca TY Sinaga ${ }^{1}$, Hetti Rusmini ${ }^{2}$, Alfi Wahyudi ${ }^{3}$, Retno AS Soemarwoto ${ }^{4}$, \\ Anse DV Messah ${ }^{5}$, Intan Utami Putri ${ }^{6}$ \\ ${ }^{1)}$ Departemen Pulmonologi Fakultas Kedokteran Universitas Malahayati,fransiscatysinaga@gmail.com \\ ${ }^{2}$ Departemen Farmakologi Fakultas Kedokteran Universitas Malahayati, hettirusmini@gmail.com \\ ${ }^{3)}$ Departemen Radiologi Fakultas Kedokteran Universitas Malahayati,wahyudi.alfi1808@gmail.com \\ ${ }^{4)}$ Departemen Pulmonologi Fakultas Kedokteran Universitas Malahayati,arizapulmo@gmai;.com \\ ${ }^{5)}$ Konsultan Radiologi RSUD Menggala, dianamessah@gmail.com \\ 6) Fakultas Kedokteran Universitas Malahayati, intanutamiputri0907@gmail.com
}

\begin{abstract}
ABSTRAK
Coronavirus Disease 2019 (COVID-19) adalah penyakit menular yang disebabkan oleh Severe Acute Respiratory Syndrome Coronavirus 2 (SARS-CoV-2). Penularan cepat dari manusia-ke-manusia melalui aerosol, droplet, dan penularan kontak langsung, mempercepat penyebaran SARS-CoV-2 di berbagai belahan dunia. Radiografi toraks dapat digunakan untuk memantau perkembangan kelainan paru akibat COVID-19, menjadi acuan bagi tenaga medis dalam melakukan skrining bagi pasien yang dicurigai terinfeksi COVID-19, serta untuk mempelajari prognosis pasien COVID-19. Tujuan dari penelitian ini adalah untuk mengetahui hubungan antara karateristik gambaran distribusi lesi radiografi toraks dengan prognosis pasien COVID-19 di Kota Bandar Lampung Tahun 2020.Penelitian ini merupakan penelitian deskriptif analitik dengan pendekatan retrospektif. Data ekspertise rekam medik radiologi dalam penelitian ini dibaca oleh dua dokter spesialis radiologi selaku observer. Analisa data yang digunakan yaitu analisis univariat serta analisis bivariat menggunakan uji korelasi Spearman. Hasil uji statistik menggunakan Uji Korelasi Spearman menunjukkan bahwa terdapat hubungan antara karakteristik gambaran distribusi lesi radiografi toraks dengan prognosis pasien terkonfirmasi positif COVID-19 di Kota Bandar Lampung tahun 2020, p-value =0,001 ( $r=0,203$ hubungan lemah)terhadap gambaran radiografi toraks keterlibatan paru, $p$-value $=0,002(r=0,188$ hubungan lemah)terhadap gambaran radiografi toraks distribusi lesi atas ke bawah, serta p-value $=0,030(r=0,135$ hubungan lemah)terhadap gambaran radiografi toraks distribusi lesi sentral ke perifer. Kesimpulan dari penelitian ini adalah terdapat hubungan yang bermakna antara karakteristik gambaran distribusi lesi radiografi toraks dengan prognosis pasien COVID-19 di Kota Bandar Lampung tahun 2020.
\end{abstract}

Kata kunci: COVID-19, Distribusi Lesi, Radiografi Toraks, Prognosis

\begin{abstract}
Coronavirus Disease 2019 (COVID-19) is an infectious disease caused by Severe Acute Respiratory Syndrome Coronavirus 2 (SARS-CoV-2). The transmission rapidly from human to human via aerosol droplets and direct contact, accelerating the spread of SARS-CoV-2 in various parts of the world. Chest radiograph can be used to monitor the development of pulmonary disorders due to COVID-19, a reference for medical personnel in screening for patients who are suspected of being infected to COVID-19, and to study the prognosis of patients COVID-19 as well. The aims of this study was to determine the relationship between the characteristics of the distribution of chest radiograph lesions and the prognosis of COVID-19 patients in Bandar Lampung City in 2020. This study was a descriptive analytic study with a retrospective approach. Analysis of the data used are univariate analysis and bivariate analysis using the Spearman correlation test. The results of statistical tests using the Spearman Correlation Test showed that there was a relationship between the characteristics of the distribution of chest radiograph lesions and the prognosis of patients who were confirmed positive for COVID-19 in Bandar Lampung City in 2020, $p$-value $=0.001$ ( $r=0.203$ weak relationship) on the chest radiograph features of involvement lung, $p$ value $=0.002(r=0.188$ weak relationship) on the chest radiograph distribution of lesions from top to bottom, and $p$-value $=0.030(r=0.135$ weak relationship) on the chest radiograph distribution of central to peripheral lesions. The conclusion of this study is that there is a significant relationship between the characteristics of the distribution of chest radiograph lesions and the prognosis of COVID-19 patients in Bandar Lampung City in 2020.
\end{abstract}

Keywords: COVID-19, Distribution of Lesions, Chest Radiograph, Prognosis

*Korespondensi Author : Intan Utami Putri, Fakultas Kedokteran Universitas Malahayati,
intanutamiputri0907@gmail.com dan+6288287249477




\section{PENDAHULUAN}

Coronavirus Disease 2019 (COVID-19) adalah penyakit menular yang disebabkan oleh Severe Acute Respiratory Syndrome Coronavirus 2 (SARS-CoV-2), yang merupakan coronavirus jenis baru dan belum pernah teridentifikasi sebelumnya. Masa inkubasi ratarata SARS-CoV-2 sekitar 5-6 hari, dengan masa inkubasi terpanjang yaitu 14 hari. ${ }^{1}$ Tanda dan gejala umum yang ditemukan pada pasien COVID-19 antara lain batuk (67,8\%), demam (43,4\%), fatigue $(38,1 \%)$, sesak napas $(18,7 \%)$, dan nyeri tenggorokan $(13,9 \%){ }^{2}$ Meskipun virus corona baru ini termasuk penyakit zoonosis (penyakit yang ditularkan melalui hewan), virus ini dapat menyebar melalui berbagai cara lainnya.Infeksi COVID-19 yang dimulai dari infeksi hewan-ke-manusia, telah berkembang, sehingga menyebabkan penularan cepat dari manusia-ke-manusia melalui aerosol, droplet, dan penularan kontak langsung. ${ }^{3}$ Hal ini mempercepat penyebaran SARS-CoV-2 di berbagai belahan dunia.

World Health Organization (WHO) resmi menetapkan COVID-19 dengan status pandemi pada tanggal 11 Maret 2020, mengingat tingkat penyebaran COVID-19 yang sangat mengkhawatirkan. Per tanggal 5 Oktober 2020, terdapat 35.109.317 kasus COVID-19 terkonfirmasi secara global dengan 1.035.341 kasus kematian di seluruh dunia. ${ }^{4}$ Per tanggal 5 Oktober 2020, terdapat 307.120 kasus terkofirmasi positif COVID-19 di Indonesia, dengan 232.593 kasus pasien sembuh dan 11.253 kasus meninggal dunia. ${ }^{5}$ Dan per tanggal 7 Oktober 2020, terdapat 1.031 kasus terkonfirmasi positif COVID-19 di Provinsi Lampung, dengan 38 kasus kematian dan 752 kasus terkonfirmasi. Jumlah pasien terinfeksi COVID-19 di Kota Bandar Lampung diprediksi akan terus meningkat, sehingga diperlukan adanya upaya pengontrolan penyebaran virus. ${ }^{6}$

Peran diagnostik dalam pandemi COVID-

19 ini sangat penting dalam mengontrol penyebaran virus.Pemeriksaan laboratorium dan pemeriksaan radiologi dapat digunakan dalam tindakan skrining dan penegakkan diagnosis COVID-19. ${ }^{7}$ Salah satu teknik yang digunakan dalam pemeriksaan radiologi yaitu radiografi toraks. Radiografi toraks dapat dijadikan sebagai tindakan diagnostik alternatif untuk mengetahui gambaran radiologi pasien COVID19.Selain dapat menjadi teknik diagnostik alternatif disaat minimnya ketersediaan RTPCR.Radiografi toraks dapat digunakan untuk memantau perkembangan kelainan paru akibat COVID-19. ${ }^{8}$ Radiografi toraksdapat menjadi acuan bagi tenaga medis dalam melakukan skrining bagi pasien yang dicurigai terinfeksi COVID-19.

Keterlibatan paru bilateral (93\%) dan distribusi lesi perifer $(87,4 \%)$, merupakan temuan umum pada gambaran radiologi pasien COVID-19. ${ }^{9}$ Hasil penelitian mengenai prognosis pasien COVID-19 berdasarkan hasil gambaran radiografi toraks menunjukkan bahwa kekeruhan paru-paru lebih luas terkait dengan hasil yang buruk pada pasien COVID-19. ${ }^{10}$ Namun, minim penelitian terkait di Kota BandarLampung, sedangkan angka prevalensi kasus COVID-19 di Kota Bandar Lampung terus meningkat. Penelitian ini sangat diperlukan, untuk mempelajari prognosis pasien berdasarkan hasil pemeriksaan radiografi toraksnya.

\section{METODOLOGI}

Penelitian ini merupakan penelitian deskriptif analitik dan dirancang menggunakan menggunakan pendekatanRetrospektif. Penelitian ini dilaksanakan di Instalasi Rekam Medik sejak bulan Februari- Maret tahun 2021. Data rekam medik didapatkan dari tiga rumah sakit di Kota Bandar Lampung, yaitu RSUD Dr. H. Abdul Moeloek, RS Advent Bandar Lampung, dan RS Pertamina Bintang Amin Bandar Lampung.

Dari total 421 populasi pasien terkonfirmasi positif COVID-19, didapatkan sebanyak 309 pasien yang memenuhi kriteria inklusi dan eksklusi untuk menjadi responden dalam penelitian ini. Kriteria inklusi yang digunakan yaitu, merupakan pasien terkonfirmasi COVID-19 baik yang sembuh, maupun meninggal dunia, serta memiliki catatan rekam medik di rumah sakit di Kota Bandar Lampung. Sementara itu, kriteria eksklusi yang 
digunakan yaitu, tidak melakukan pemeriksaan radiografi toraks, prognosis pasien tidak diketahui, serta meninggal dunia sebelum dilakukan pemeriksaan radiografi toraks.

Ekspertis data rekam medik radiologi pasien COVID-19 dibaca dan disetujui oleh dua dokter spesialis radiologi selaku observer dalam penelitian ini. Pengelompokkan, penyusunan, pengkodean, serta interpretasi data disajikan dalam bentuk tabel. Peneliti melakukan analisis univariat distribusi frekuensi dan analisis bivariat Spearman Correlation Test ke dalam aplikasi Statistical Product and Service Solutions (SPSS) versi 20.

\section{HASIL DAN PEMBAHASAN}

Sebelum melakukan analisis data gambaran distribusi lesi pasien, peneliti menganalisi data sebaran jenis kelamin, usia, hasil bacaan radiografi toraks serta prognosis pasien. Hal ini bertujuan untuk mengetahui karakteristik responden dalam penelitian ini. Analisis univariat dilakukan dengan menggunakan sebaran distribusi frekuensi.

Tabel 1. Jenis Kelamin Responden

\begin{tabular}{ccc}
\hline Jenis Kelamin & $\mathbf{N}$ & $\mathbf{F}(\boldsymbol{\%})$ \\
\hline Laki-laki & 164 & $53,1 \%$ \\
Perempuan & 145 & $46,9 \%$ \\
\hline Total & $\mathbf{3 0 9}$ & $\mathbf{1 0 0 \%}$ \\
\hline
\end{tabular}

Berdasarkan tabel 1, diketahui bahwa karakteristik responden pasien COVID-19 yang berjumlah 309 pasien berdasarkan jenis kelamin sebagian besar yaitu laki-laki sebanyak 164 pasien $(53,1 \%)$ dan perempuan sebanyak 145 pasien (46,9\%).Distribusi jenis kelamin yang lebih banyak pada laki-laki diduga terkait dengan prevalensi perokok aktif yang lebih tinggi. Pada perokok aktif, diduga adanya peningkatan ekspresi reseptor angiotensin converting enzym 2 (ACE2), sehingga glikoprotein yang terdapat pada envelope spike virus akan berikatan dengan reseptor selular pada Coronavirus. ${ }^{11}$

Tabel 2. Usia Pasien Responden

\begin{tabular}{ccc}
\hline Usia & $\mathbf{N}$ & $\mathbf{F}(\%)$ \\
\hline Balita $(0-1$ tahun $)$ & 1 & $0,3 \%$ \\
\hline
\end{tabular}

\begin{tabular}{ccc} 
Usia & $\mathbf{N}$ & $\mathbf{F}(\%)$ \\
\hline Anak-anak (2-10 tahun) & 1 & $0,3 \%$ \\
Remaja (11-19 tahun) & 2 & $0,6 \%$ \\
Dewasa (20-60 tahun) & 233 & $75,4 \%$ \\
Lansia (>60 tahun) & 72 & $23,3 \%$ \\
\hline Total & $\mathbf{3 0 9}$ & $\mathbf{1 0 0 \%}$ \\
\hline
\end{tabular}

Berdasarkan tabel 2, karakteristik responden pasien COVID-19 yang berjumlah 309 pasien dengan usia paling sering ditemukan yaitu usia lansia berjumlah 156 pasien $(50,5 \%)$, diikuti oleh usia dewasa sebanyak 85 pasien $(27,5 \%)$. Usia manula sebanyak 46 pasien $(14,9 \%)$, usia remaja sebanyak 20 pasien $(6,5 \%)$, dan usia paling jarang ditemukan yaitu usia balita dan anak-anak yang masing-masing berjumlah 1 pasien $(0,3 \%)$. Pasien responden usia dewasa pada penelitian tersebut rata-rata mengalami diabetes melitus, hipertensi, tuberkulosis, penyakit paru obstruktif kronis, penyakit jantung, chronic kidney disease, stroke, ibu hamil, asma, serta pasien HIV/AIDS. Penyakit-penyakit tersebut merupakan faktor komorbid yang rentan terinfeksi COVID-19. ${ }^{11}$

Tabel 3. Hasil Bacaan Radiografi Toraks Responden

\begin{tabular}{ccc}
\hline $\begin{array}{c}\text { Hasil Bacaan } \\
\text { Radiografi Toraks }\end{array}$ & $\mathbf{N}$ & $\mathbf{F}(\boldsymbol{\%})$ \\
\hline Normal & 51 & $16,5 \%$ \\
Tidak Normal & 258 & $83,5 \%$ \\
\hline Total & $\mathbf{3 0 9}$ & $\mathbf{1 0 0 \%}$ \\
\hline
\end{tabular}

Berdasarkan tabel 3, diketahui bahwa karakteristik responden pasien COVID-19 berdasarkan hasil bacaan radiografi toraks yang paling sering detemukan yaitu hasil bacaan radiografi toraks tidak normal sebanyak 258 pasien $(83,5 \%)$. Sementara itu, hasil bacaan radiografi toraks normal ditemukan pada 51 pasien $(16,5 \%)$. Gambaran radiografi toraks yang normal tidak menyingkirkan diagosis COVID-19, sehingga tindakan isolasi tetap dilakukan. ${ }^{12}$

Tabel 4. Prognosis Pasien Responden

\begin{tabular}{ccc}
\hline Prognosis & N & F(\%) \\
\hline Sembuh & 277 & $89,6 \%$ \\
Meninggal Dunia & 32 & $10,4 \%$ \\
\hline
\end{tabular}




\begin{tabular}{ccc}
\hline Prognosis & N & F(\%) \\
\hline Total & 309 & $\mathbf{1 0 0 \%}$ \\
\hline
\end{tabular}

Berdasarkan tabel 4, diketahui bahwa prognosis pasien COVID-19 yang paling sering ditemukan yaitu pasien sembuh sebanyak 277 pasien $(89,6)$, sedangkan pasien meninggal dunia sebanyak 32 pasien $(10,4 \%)$. Penelitian serupa yang sebelumnya dilakukan di Kabupaten Banyuwangi, didapatkan bahwa sebanyak 44 pasien $(78,5 \%)$ terkonfirmasi COVID-19 dinyatakan sembuh (prognosis baik). ${ }^{13}$ Sementara itu, data pasien COVID-19 di RSUD Dr. Soetomo, Surabaya, Jawa Timur melaporkan bahwa pada kasus pasien terkonfirmasi COVID-19, mortalitas atau tingkat kematian hanya terjadi pada sekitar 8-10\% pasien. Hal ini membuktikan bahwa pasien meninggal (prognosis buruk) hanya ditemukan pada 8-10\% kasus kejadian COVID-19. ${ }^{14}$

Sementara itu, data distribusi frekuensi responden berdasarkan distribusi lesi paru, ditentukan melalui keterlibatan paru, distribusi lesi atas ke bawah, serta distribusi lesi sentral ke perifer. Dilakukan analisis distribusi frekuensi sebagai bentuk dari analisis univariat. Data distribusi frekuensi responden berdasarkan distribusi lesi paru, disajikan dalam tabel berikut.

Tabel 5. Distribusi Frekuensi Distribusi Lesi

\begin{tabular}{ccc}
\hline Keterlibatan Paru & $\mathbf{N}$ & $\mathbf{F}(\%)$ \\
\hline Paru Kanan & 49 & $19,1 \%$ \\
Paru Kiri & 23 & $8,9 \%$ \\
Bilateral & 109 & $42,4 \%$ \\
Tidak Tampak & 76 & $29,6 \%$ \\
\hline Atas ke Bawah & $\mathbf{N}$ & $\mathbf{F}(\boldsymbol{\%})$ \\
\hline Zona Atas & 5 & $1,9 \%$ \\
Zona Tengah & 10 & $3,9 \%$ \\
Zona Bawah & 119 & $46,3 \%$ \\
Campuran & 10 & $3,9 \%$ \\
Tidak Tampak & 113 & $44 \%$ \\
\hline Sentral ke Perifer & $\mathbf{N}$ & $\mathbf{F}(\%)$ \\
\hline Perifer & 4 & $1,6 \%$ \\
Sentral & 89 & $34,6 \%$ \\
Campuran & 2 & $0,8 \%$ \\
Tidak Tampak & 162 & $63 \%$ \\
\hline Total & $\mathbf{2 5 7}$ & $\mathbf{1 0 0 \%}$ \\
\hline
\end{tabular}

Berdasarkan tabel 5, diketahui bahwa distribusi lesi keterlibatan paru pasien COVID19 yang paling sering ditemukan adalah pada keterlibatan paru bilateral sebanyak 109 pasien $(42,4 \%)$, dan yang paling jarang ditemukan adalahketerlibatan paru kiri sebanyak 23 pasien $(8,9 \%)$. Distribusi lesi atas ke bawah pasien COVID-19 yang sering ditemukan adalah distribusi lesi pada zona bawah sebanyak 119 pasien (46,3\%), dan distribusi lesi atas ke bawah yang jarang ditemukan adalah pada zona atas sebanyak 5 pasien $(1,9 \%)$. Tidak tampaknya distribusi sentral ke perifer ditemukan terbanyak pada 162 pasien (63\%) dan distribusi lesi sentral ke perifer yang jarang ditemukan adalah pada campuran lesi sentral dan perifer yaitu sebanyak 2 pasien $(0,8 \%)$.

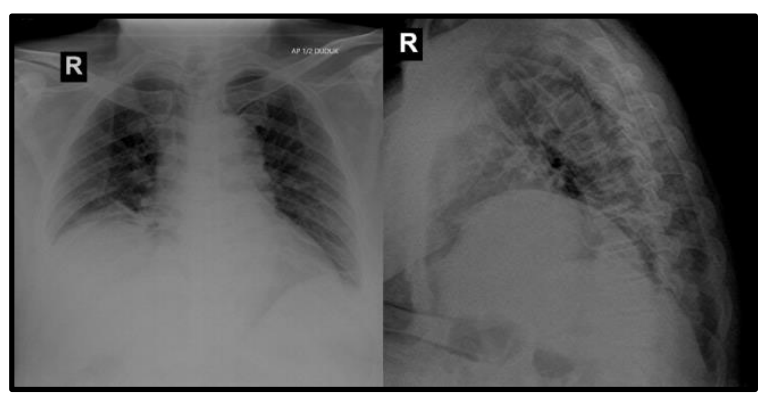

Gambar 1. Gambaran radiografi toraks distribusi lesi. (Kiri) Seorang laki-laki 55 tahun, pasien terkonfirmasi positif COVID-19, yang memiliki gambaran radiografi toraks pneumonia di bilateral zona bawah sentral, diikuti dengan kardiomegali dilihat dari sisi AP, (Kanan) dilihat dari sisi lateral.

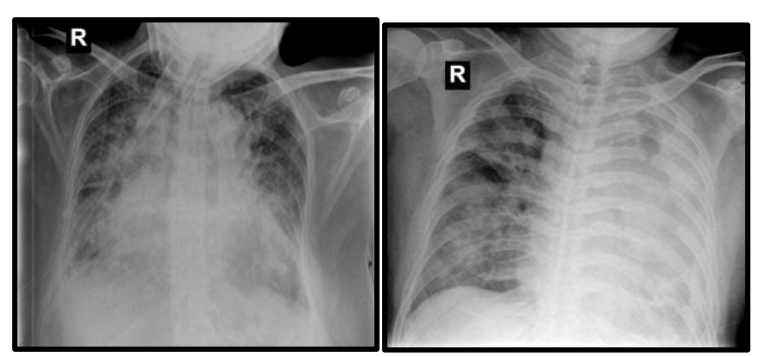

Gambar 2. Gambaran radiografi toraks pasien terkonfirmasi positif COVID-19 yang meninggal dunia. (Kiri) Wanita 57 tahun dengan gambaran radiografi toraks kardiomegali serta infiltrat di zona tengah sentral dan zona bawah sentral bilateral (Kanan) Laki-laki 48 tahun dengan gambaran radiografi toraks efusi pleura sinistra disertai infiltrat bilateral. 
Tabel 6. Hubungan Gambaran Distribusi Lesi dengan Prognosis Pasien COVID-19

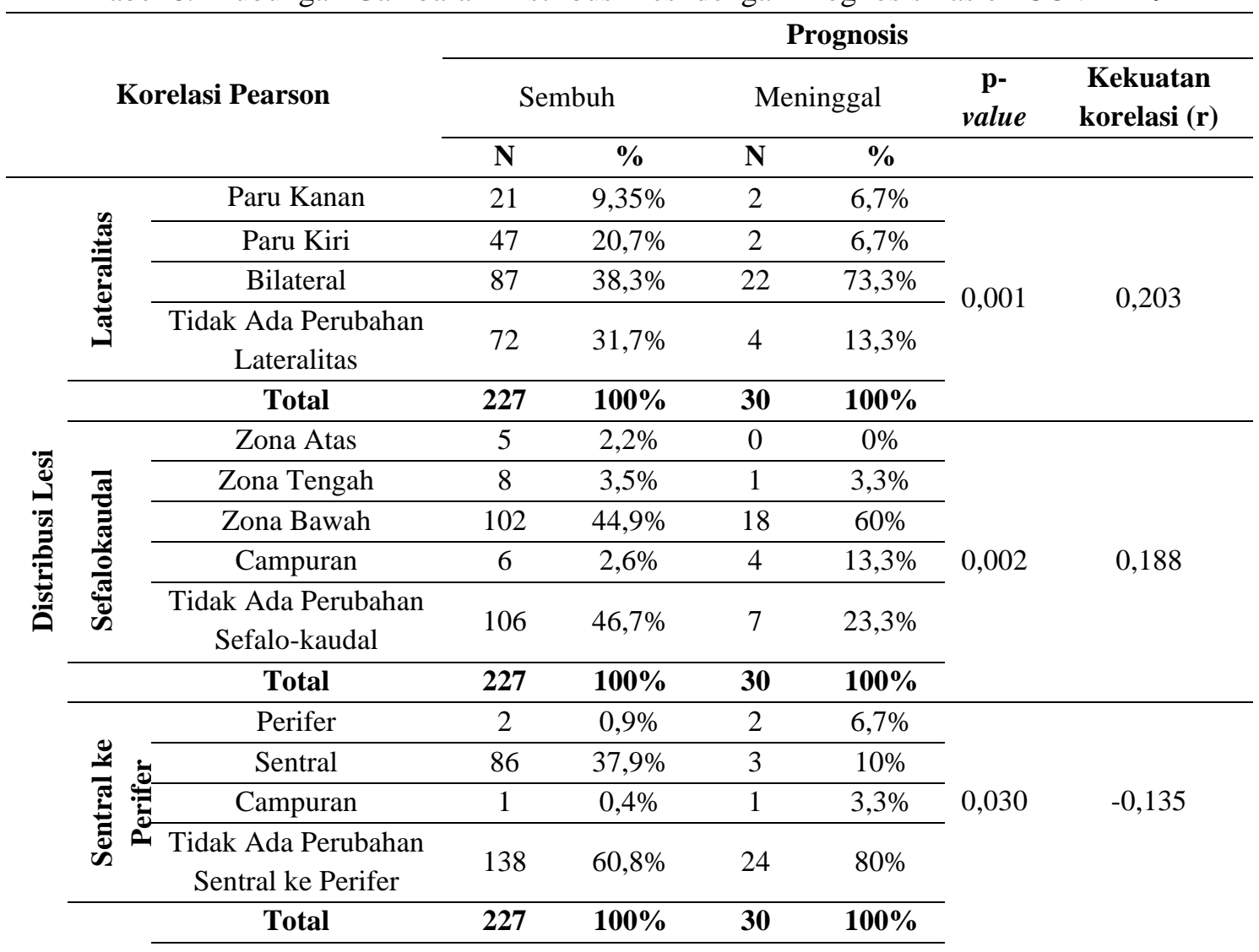

Berdasarkan tabel 6, didapatkan bahwa terdapat hubungan yang signifikan antara keterlibatan paru dengan prognosis pasien terkonfirmasi positif COVID-19 di Kota Bandar Lampung tahun 2020, dengan nilai p-value $=$ 0,001 . Hasil analisis menunjukkan, kekuatan korelasi berada di angka 0,203, yang berarti hubungan yang terjadi merupakan hubungan yang lemah. Arah korelasi menunjukkan (+), yaitu hubungan yang searah.

Didapatkan bahwa terdapat hubungan yang signifikan antara distribusi lesi atas ke bawah dengan prognosis pasien terkonfirmasi positif COVID-19 di Kota Bandar Lampung tahun 2020, dengan nilai p-value $=0,002$. Hasil analisis menunjukkan, kekuatan korelasi berada di angka 0,188, yang berarti hubungan yang terjadi merupakan hubungan yang lemah. Arah korelasi menunjukkan (+), yaitu hubungan yang searah.

Didapatkan bahwa terdapat hubungan yang signifikan antara distribusi lesi sentral ke perifer dengan prognosis pasien terkonfirmasi positif COVID-19 di Kota Bandar Lampung tahun 2020, dengan nilai p-value $=0,030$. Hasil analisis menunjukkan, kekuatan korelasi berada di angka $-0,135$, yang berartihubungan yang terjadi merupakan hubungan yang lemah. Arah korelasi menunjukkan (-), yaitu hubungan yang tidak searah.

Keterlibatan paru bilateral dikaitkan dengan adanya perubahan patologis. Hal tersebut disebabkan oleh mekanisme patologis penyebaran Coronavirus, termasuk kerentanan bronkiolus, parenkim paru, yang dapat menyebar ke semua lobus paru sehingga menyebabkan gangguan difusi lobular. Sampel biopsi yang diambil dari paru kanan dan paru kiri menunjukkan kerusakan alveolar bilateral difus. ${ }^{15}$

Zona bawah sentral dikaitkan dengan anatomi dari bronkus lobus inferior kanan yang lebih lurus dan curam dibandingkan cabang bronkial lainnya. Sudut antara lobus kanan 
bawah dan panjang trakea lebih kecil. Oleh karena itu, pada fase awal penyakit, virus lebih mungkin menyerang cabang bronkus lobus inferior kanan dan menyebabkan infeksi. ${ }^{16}$

\section{SIMPULAN DAN SARAN}

Berdasarkan hasil analisis dan pembahasan penelitian, maka dapat ditarik kesimpulan bahwa karakteristik pasien terkonfirmasi positif COVID-19 di Kota Bandar Lampung tahun 2020 adalah pasien laki-laki $(53,1 \%)$, usia dewasa $20-60$ tahun $(75,4 \%)$. Hasil bacaan radiologi tidak normal $(83,5 \%)$ dan pasien sembuh prognosis baik $(89,6 \%)$. Gambaran radiografi toraks distribusi lesi paru yang paling banyak ditemukan yaitu keterlibatan paru bilateral $(42,4 \%)$, zona bawah $(46,3 \%)$, dan tidak tampak lesi sentral ke perifer $(63 \%)$.

Terdapat hubungan antara gambaran distribusi lesi paru dengan prognosis pasien COVID-19 di Kota Bandar Lampung tahun 2020. Nilai p-value keterlibatan paru $=0,001(\mathrm{r}$ $=0,203$ hubungan lemah). Nilai p-value distribusi lesi atas ke bawah $=0,002(\mathrm{r}=0,188$ hubungan lemah). Sementara itu, nilai p-value distribusi lesi sentral ke perifer $=0,030(\mathrm{r}=$ 0,135 hubungan lemah).

Saran bagi masyarakat agar melakukan pemeriksaan radiografi toraks, sehingga dapat membantu tenaga kesehatan dalam melakukan diagnosis serta pencegahan prognosis buruk. Saran bagi institusi pendidikan agar penelitian ini dapat menjadi bahan referensi dalam pembelajaran bagi seluruh institusi pendidikan bidang kesehatan di seluruh Indonesia. Saran untuk penelitian selanjutnya, dapatmenambah jumlah variabel dan sampel, serta melakuakan penelitian berdasarkan rekapan evaluasi hasil ekspertise radiologi pasien pada data rekam medik.

\section{UCAPAN TERIMA KASIH}

Peneliti mengucapkan terima kasih kepada seluruh pihak yang terkait dalam penyelenggaraan penelitian ini, terkhusus Fakultas Kedokteran Universitas Malahayati, RSUD Dr. H. Abdul Moeloek Prov. Lampung, RS Advent Bandar Lampung, dan RS Pertamina Bintang Amin Bandar Lampung.

\section{REFERENSI}

1. Kementerian Kesehatan Republik Indonesia; KEMENKES RI. Pedoman Pencegahan dan Pengendalian Coronavirus Diseasae (COVID19) Revisi Ke-5. Indonesia; 2020.

2. Guan W, Ni Z, Hu. Clinical Characteristics of Coronavirus Disease 2019 in China. NEJM: New england journal of medicine. 2020; 382 (18): 1708-1720.

3. Rahman HS, Aziz MS, Hussein RH. The transmission modes and sources of COVID-19; A systematic review. International Journal of Surgery Open. 2020; 26 (2020): 125-136.

4. World Health Organization [homepage on the Internet]. WHO Coronavirus Disease (COVID19) Dashboard. Data last updated: $2020 / 10 / 5$, 3:54 CEST [diakses pada tanggal 62020 Oktober]. Available from: https://covid19.who.int/.

5. Kementerian Kesehatan Republik Indonesia [homepage on the Internet]. Situasi COVID-19, Kondisi 5 Oktober 2020 [diakses pada tanggal 6 Oktober 2020]. Available from: https://www.kemkes.go.id/.

6. Dinas Kesehatan Provinsi Lampung [homepage on the Internet]. Data Pantauan COVID-19 di Provinsi Lampung [diakses pada tanggal 7 Oktober 2020]. Available from: http://dinkes.lampungprov.go.id/covid19/.

7. Shahzeb M, Khan A, Muhammad A. Detection of coronavirus disease (COVID-19) using radiological examinations. J Pure Appl Microbiol 14.suppl 1 (2020): 911-920.

8. Wong HYF, Lam HYS, Fong AHT. Frequency and Distribution of Chest Radiographic Findings in Patients Positive for COVID-19. Radiology, 2020; 296(2), pp. E72-E78.

9. Abrishami A, Khalili N, Dalili N. Clinical and Radiologic Characteristics of COVID-19 in Patients With CKD. Iran J Kidney Dis, 2020; 14(4), 267-77.

10. Kerpel A, Apter S, Nissan N. Diagnostic and prognostic value of chest radiographs for COVID-19 at presentation. Western Journal of Emergency Medicine 21.5 (2020): 1067.

11. Susilo A, Rumende CM, Pitoyo CW. Coronavirus Disease 2019: Tinjauan Literatur Terkini. Jurnal Penyakit Dalam Indonesia, 2020; 7(1), p. 45.

12. Tapé C, Byrd KM, Aung S. COVID-19 in a Patient Presenting with Syncope and a Normal Chest X-ray. Rhode Island medical journal, 2013; 103(3), 50-51. 
13. Sulantari S, dan Hariadi W. Analisis Survival Waktu Sembuh Pasien COVID-19 di Kabupaten Banyuwangi. Transformasi : Jurnal Pendidikan Matematika Dan Matematika, 2020; 4(2), 375386.

14. SMF Pulmonologi dan Ilmu Kedokteran Respirasi. Panduan Praktik Klinis; Pneumonia COVID-19. Indonesia; 2020.

15. Zheng Q, Lu Y, Lure F. Clinical and Radiological Features of Novel Coronavirus Pneumonia. Journal of X-Ray Science and Technology, 2020; 28(3),391-404.

16. Zhou S, Wang Y, Zhu T. CT features of coronavirus disease 2019 (COVID-19) pneumonia in 62 patients in Wuhan, China. American Journal of Roentgenology, 2020; 214(6), pp. 1287-1294. 